\title{
Investigation of Combined S02/NOx Removal by Ceria Sorbents
}

\author{
Quarterly Report \\ April 1 - June 30, 1996
}

RECEIVE

\author{
By \\ Ates Akyurtlu \\ Jale F. Akyurtlu
}

NOV 23900

OSTI

\author{
Work Performed Under Contract No.: DE-PS22-92MT92018 \\ For \\ U.S. Department of Energy \\ Office of Fossil Energy \\ Federal Energy Technology Center \\ P.O. Box 880 \\ Morgantown, West Virginia 26507-0880
}

By

Hampton University

Department of Engineering

Hampton, Virginia 23668 


\section{Disclaimer}

This report was prepared as an account of work sponsored by an agency of the United States Government. Neither the United States Government nor any agency thereof, nor any of their employees, makes any warranty, express or implied, or assumes any legal liability or responsibility for the accuracy, completeness, or usefulness of any information, apparatus, product, or process disclosed, or represents that its use would not infringe privately owed rights. Reference herein to any specific commercial product, process, or service by trade name, trademark, manufacturer, or otherwise does not necessarily constitute or imply its endorsement, recommendation, or favoring by the United States Government or any agency thereof. The views and opinions of authors expressed herein do not necessarily state or reflect those of the United States Government or any agency thereof. 


\section{DISCLAIMER}

Portions of this document may be illegible in electronic image products. Images are produced from the best available original document. 


\title{
Table of Contents
}

Abstract

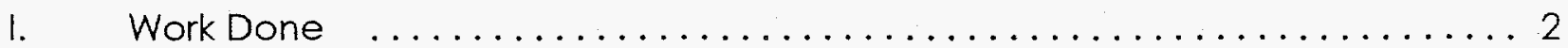

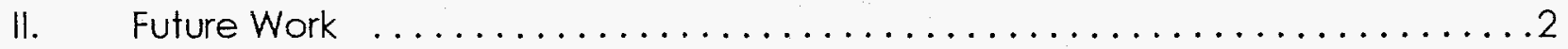

\begin{abstract}
Simultaneous removal of $\mathrm{SO}_{2}$ and $\mathrm{NO}_{x}$ using a regenerable solid sorbent will constitute an important improvement over the use of separate processes for the removal of these two pollutants from stack gases and possibly eliminate several shortcomings of the individual $\mathrm{SO}_{2}$ and $\mathrm{NO}_{x}$ removal operations. Recent studies at PETC considered cerium oxide as an alternatesorbent to CuO.

The present study aims to determine the effects of ammonia on the sulfation of the sorbent and to obtain a rate expression for the regeneration of alumina-supported $\mathrm{CeO}_{2}$ sorbents. In the past quarter the effect of fly-ash, ammonia, and water on the sulfation of the sorbent was investigated. The analysis of the economics of a commercial scale ceria process has been sub-contracted to TECOGEN. This work has been completed and the report has been received.
\end{abstract}




\section{WORK DONE}

In this quarter of the project, the main focus was on completion of the experimental program for the determination of the effect of fly-ash, ammonia, and water on the sorbent performance. All the planned experiments have been completed. The analysis and evaluation of the final set of data are being conducted and the results will be reported in the final report. Since the evaluation of the previous data indicated some concern about the accuracy of the metal analyses, a control sample was sent to a different laboratory for confirmation. The results are not received yet.

The report from the subcontractor (TECOGEN of Waltham, MA) for the commercial scale evaluation of the ceria process has been received and reviewed. It will be included in its revised form in the final project report.

\section{FUTURE WORK}

In the next quarter, it is planned:

1) to write the final report. 